\title{
Synthesis of Intermediates Related to Diphenyl Ether Herbicides
}

\author{
Takeo Yoshimoto, Keiichi Igarashi, Takashi Fujita \\ and Takeo Harayama \\ Life Science Business Development Department, \\ Mitsui-Toatsu Chemicals Inc., Chiyoda-ku, Tokyo 100, Japan
}

(Received January 27, 1990)

\begin{abstract}
An investigation was carried out to obtaining basic compounds that would be useful intermediates of diphenyl ether herbicide. In industrial practice, 2,4-dichloronitrobenzene has long been used as a starting material for diphenyl ether herbicide through 2,4-bis(substituted phenoxy)nitrobenzene (2). The authors chose 3,4-dinitrochlorobenzene (1) as a candidate substitute for 2,4-dichloronitrobenzene and had experimental studies to clarify the difference in reactivity and selectivity between the two compounds. First, (2) was efficiently prepared by reaction between (1) and phenols, and, 2-chloro-4-trifluoromethylphenyl 3,4-dinitrophenyl ether (3) was prepared as a replaceable derivative of (1). The 3-nitro group of (3) retained good reactivity with a nucleophilic reagent, as such as the case with (1). Next, (2) and (3) were derived to substituted phenyl 3-hydroxy-4-nitrophenyl ether (4) by hydrolytic cleavage with sodium hydroxide or potassium hydroxide. Thus obtained (2), (3) and (4) would be important intermediates for diphenyl ether herbicides with the nitro group at the 4-position.
\end{abstract}

\section{INTRODUCTION}

It is a long time since diphenyl ether compounds began to attract attention as herbicides. In the early 1960's Rohm \& Haas Co. (R \& H) succeeded in commercial development of herbicides from diphenyl ether compounds, nitrofen and TOPE, and the interest of the world's major chemical companies in this type of compounds was aroused by this success. Research and development in this field have continued and many kinds of herbicides have been developed. They all have the same diphenyl ether skeleton ${ }^{1)}$ but the action mechanism and herbicidal activity spectrum vary from one compound to another. Diphenyl ether compounds deserve further studies.

What interested us in particular was the group of compounds in Fig. 1 that seem to have herbicidal activity strong enough to be used in wide applications. Herbicides serve for stable agricultural production, and eco- nomical supply of the active ingredients is necessary.

Aiming at high-efficiency production of the above-mentioned compounds, we had experimental studies of highly versatile intermediates of them.

In this paper, the results of the investigation with respect to preparation of three intermediates (2), (3) and (4) shown in Fig. 2 for diphenyl ether herbicides is reported.

\section{METHODS AND RESULTS}

\section{Synthesis of 3,4-Dinitrochlorobenzene (1)}

A reactor was charged with $1000 \mathrm{~g}$ of concentrated sulfuric acid, and while the reactor was cooled in ice bath, $1000 \mathrm{~g}$ of fuming nitric acid $(d=1.5)$ was added.

To this solution kept at a temperature of $20-25^{\circ} \mathrm{C}$ was added $400 \mathrm{~g}$ (2.54 mol) of $m$ nitrochlorobenzene dropwise, and the mixture was heated at $50-60^{\circ} \mathrm{C}$ for $3 \mathrm{hr}$. When the resulting solution was poured into ice-cold 


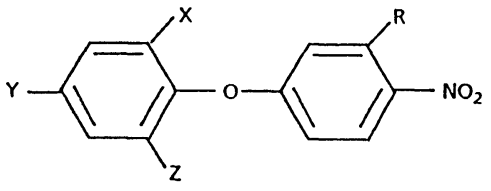

$X, Z=$ halogen, methyl.

$\gamma=$ halogen, trifluoromethyl, nitro, methylthio.

$R=$ alkoxy, alkylthio, alkylamino. alkoxycarbonylmethylthio.

Fig. 1 Basic chemical structure.
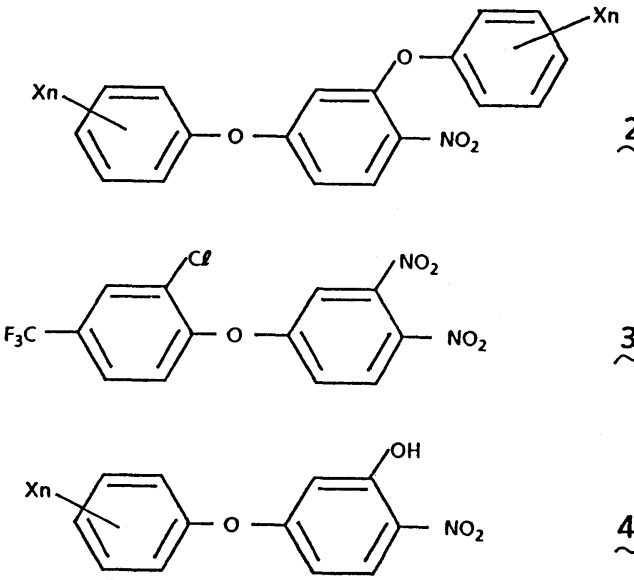

$X n=$ halogen, methyl, trifluoromethyl, nitro, methylthio

Fig. 2 Major intermediates of diphenyl ether herbicide.

water, crude crystals were formed. The product was recrystallized from ethanol to obtain $404 \mathrm{~g}$ of the purified product. The yield was $78.5 \%$ and the melting point was $38-40^{\circ} \mathrm{C}$.

This product was used as an intermediate in succeeding experiments.

2. Synthesis of 2,4-Bis(2,4-dichlorophenoxy)nitrobenzene $(\mathbf{2 a})$ and Related Compounds $(2 b)-(2 i)$

To $100 \mathrm{ml}$ of $N, N$-dimethylformamide (DMF) were added $20.3 \mathrm{~g}(0.1 \mathrm{~mol})$ of $3,4-$ dinitrochlorobenzene (or $19.2 \mathrm{~g}$ of 2,4-dichloronitrobenzene), $32.6 \mathrm{~g}(0.2 \mathrm{~mol})$ of 2,4-dichlorophenol and $27.6 \mathrm{~g}(0.2 \mathrm{~mol})$ of potassium carbonate, and the mixture was heated to $140^{\circ} \mathrm{C}$ and kept for $3 \mathrm{hr}$. When the resulting solution was poured into cooling water, an oily substance was separated. The target product was extracted with benzene. The crude yield was $93.5 \%$. Purification was done by recrystallizing from methanol. The melting point was $87.5-88.5^{\circ} \mathrm{C}$.

${ }^{1} \mathrm{H}$ NMR $\delta^{\mathrm{CDCl}_{3}} \mathrm{ppm}: 6.44(1 \mathrm{H}, \mathrm{d}, J=2.4$ $\mathrm{Hz}), 6.61(1 \mathrm{H}, \mathrm{dd}, J=8.8,2.4 \mathrm{~Hz}) 7.0-7.2(2 \mathrm{H}$, m), 7.2-7.4 (2H, m), $7.49(2 \mathrm{H}, \mathrm{d}, J=2.4 \mathrm{~Hz})$ $8.08(1 \mathrm{H}, \mathrm{d}, J=8.8 \mathrm{~Hz})$.

In the case of 3,4-dinitrochlorobenzene (1), reaction was operated at $65-85^{\circ} \mathrm{C}$ to replace the highly reactive 3 -position nitro group. Then the reaction temperature was raised up to $140-150^{\circ} \mathrm{C}$ to form bis substituent products (2). When alkali was used, (2) was obtained from hydroxide, carbonate or phenolate with a satisfactory yield, but it was found that anhydrous conditions by the use of carbonate or phenolate were desirable for getting clearer reaction mass. The yields and melting points of the products thus obtained are shown in Table 1 and Fig. 3, and the results by the use of different kinds of solvents are shown in Table 2. See also Fig. 4.

\section{Synthesis of 2,4-Bis(2-chloro-4-trifluoro- methylphenoxy)nitrobenzene $(\mathbf{2 j})$}

To $100 \mathrm{ml}$ of sulfolane solution [resorcin $11 \mathrm{~g}$ $(0.1 \mathrm{~mol})+85 \% \mathrm{KOH} 14.4 \mathrm{~g}(0.22 \mathrm{~mol})]$ was added $46 \mathrm{~g}(0.2 \mathrm{~mol})$ of 3,4-dichlorobenzotrifluide. The mixture was reacted at $160-170^{\circ} \mathrm{C}$ for $10 \mathrm{hr}$. The reaction solution was discharged into water, and the oily substance was separated and distilled in vacuo to yield $23 \mathrm{~g}$ of 1,3-bis(5-chloro-4-trifluoromethyl)benzene. The yield was $49 \%$, and the boiling point was $180-183^{\circ} \mathrm{C} / 0.4 \mathrm{mmHg}$.

To $23.4 \mathrm{~g}(0.05 \mathrm{~mol})$ of the above product dissolved in $50 \mathrm{ml}$ of acetic anhydride at a temperature below $10^{\circ} \mathrm{C}$ was added dropwise a mixture of acids (fuming nitric acid $5 \mathrm{~g}+$ concentrated sulfuric acid $4 \mathrm{~g}$ ). With stirring the reaction was brought to completion at room temperature in $24 \mathrm{hr}$. The resulting solution was discharged into ice-cold water and the precipitating crystals were collected. The crude product of $(\mathbf{2} \mathbf{j})$ was recrystallized from methanol.

The yield was $72.9 \%$ and the melting point was $101.5-103^{\circ} \mathrm{C}$. See also Fig. 5 .

IR $\mathrm{V}^{\mathrm{KBr}} \mathrm{cm}^{-1}: 1510,1310$ 
Table 1 Results of synthesis of bis-substitutes (2).

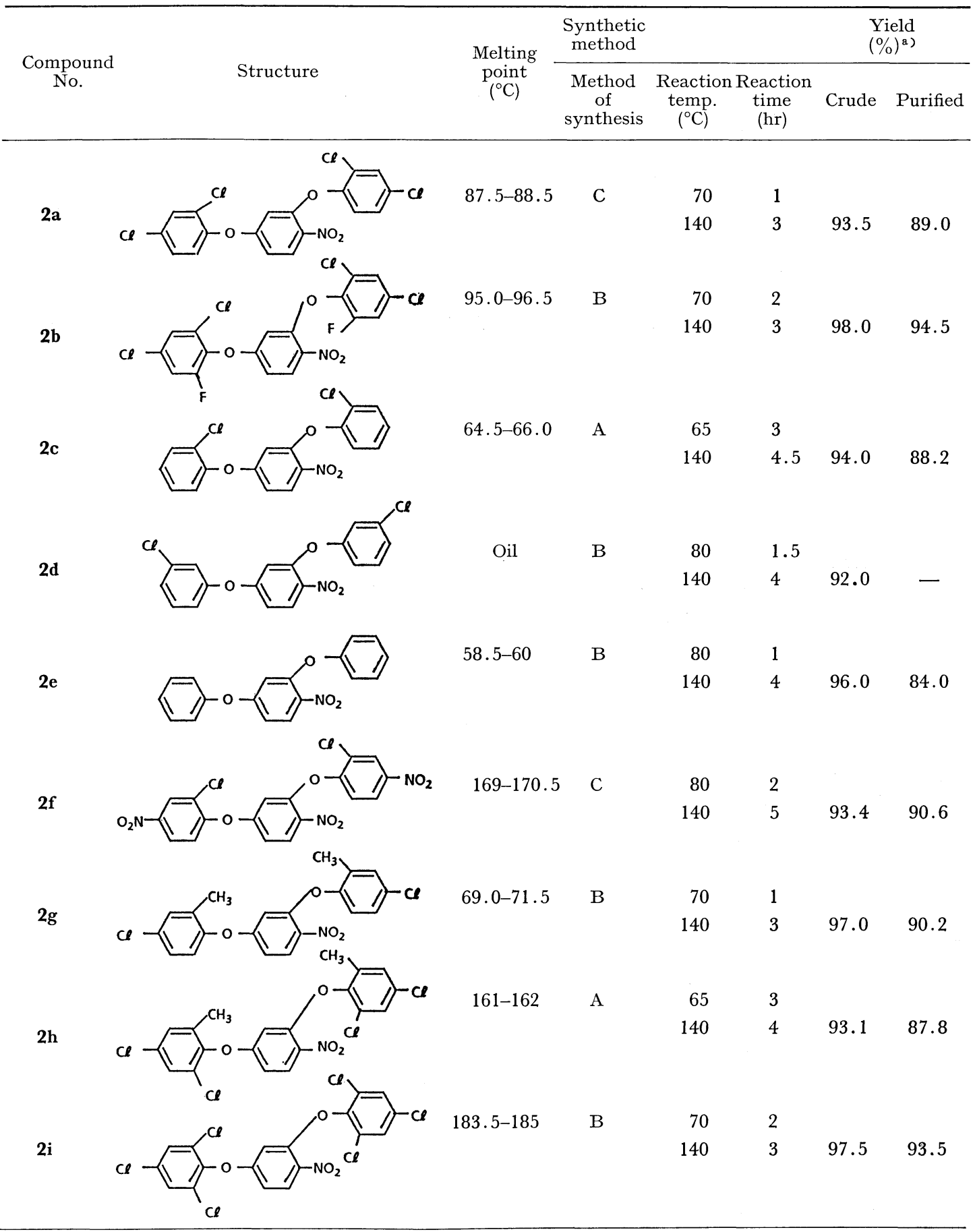

a) Yield based on 3,4-dinitrochlorobenzene. 
A)

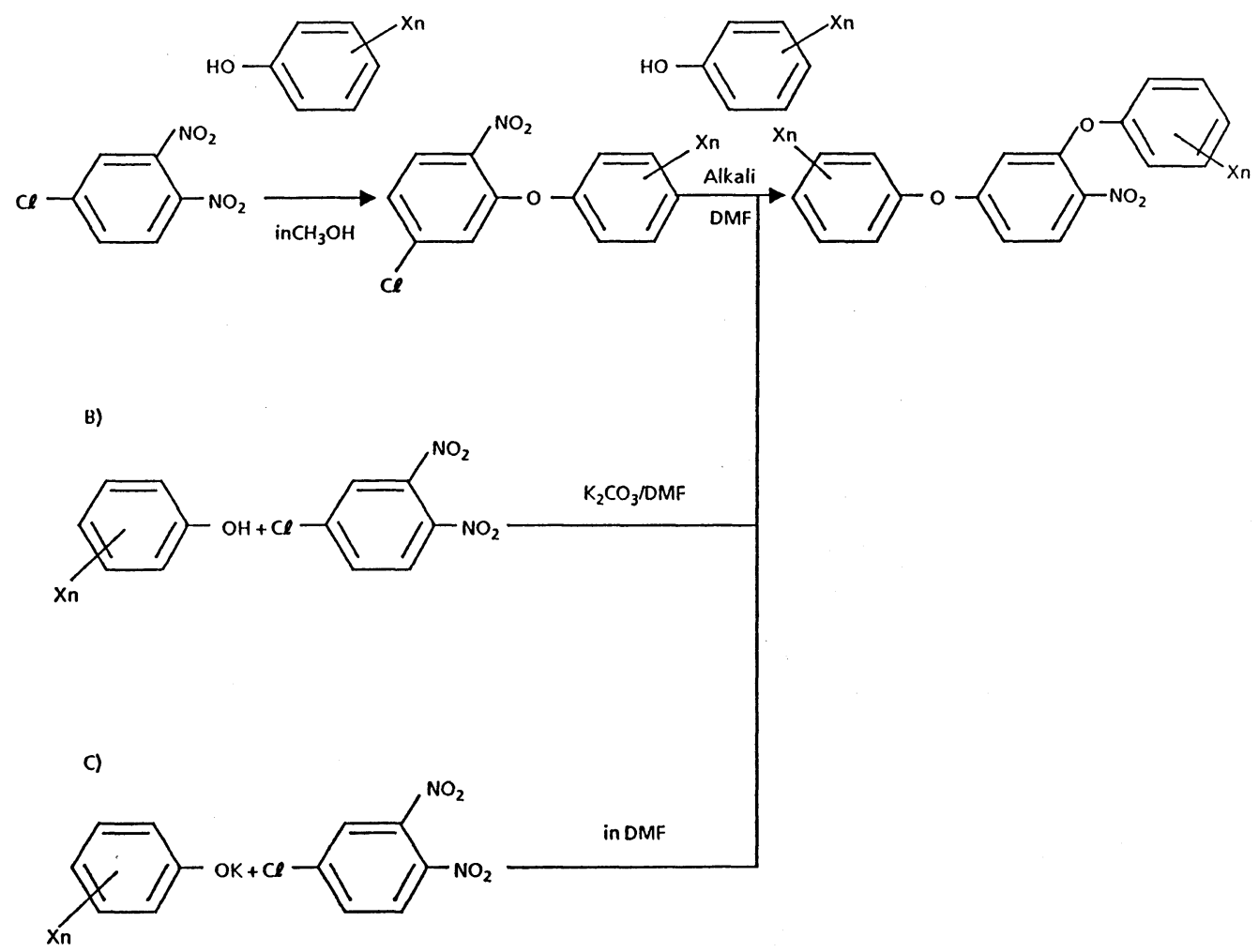

Fig. 3 Synthetic pathways of bis-substitutes (2).

Table 2 Results of synthesis of 2,4-bis-(2,4dichlorophenoxy)-nitrobenzene by using different kinds of solvents.

\begin{tabular}{|c|c|c|c|c|}
\hline \multirow{2}{*}{ Solvent } & \multicolumn{2}{|c|}{$\begin{array}{l}\text { Conditions of } \\
\text { reaction }\end{array}$} & \multicolumn{2}{|c|}{$\begin{array}{l}\text { Yield } \\
(\%)^{a)}\end{array}$} \\
\hline & $\underset{\left({ }^{\circ} \mathrm{C}\right)}{\text { Temp. }}$ & $\begin{array}{l}\text { Time } \\
\text { (hr) }\end{array}$ & Crude & Purified \\
\hline Diglyme & $\begin{array}{r}70 \\
140\end{array}$ & $\begin{array}{l}3 \\
4\end{array}$ & 91.7 & 71.0 \\
\hline DMSO & $\begin{array}{r}70 \\
150\end{array}$ & $\begin{array}{l}1 \\
2\end{array}$ & 96.5 & 90 \\
\hline Sulfolane & $\begin{array}{r}60 \\
150\end{array}$ & $\begin{array}{l}3 \\
2\end{array}$ & 97.2 & 92.3 \\
\hline Ethylene glycol & $\begin{array}{r}70 \\
140\end{array}$ & $\begin{array}{l}1 \\
3\end{array}$ & 65.0 & $21.0^{b)}$ \\
\hline $\begin{array}{l}N \text {-methyl-2- } \\
\text { pyrolydone }\end{array}$ & $\begin{array}{r}70 \\
140\end{array}$ & $\begin{array}{l}1 \\
3\end{array}$ & 88.5 & $42.5^{\mathrm{c})}$ \\
\hline $\begin{array}{l}\text { Tetraethylene glycol } \\
\text { dimethyl ether }\end{array}$ & $\begin{array}{r}70 \\
140\end{array}$ & $\begin{array}{l}1 \\
3\end{array}$ & 92.3 & 74.6 \\
\hline
\end{tabular}

a) Yield based on 3,4-dinitrochlorobenzene.

b) Purified by column chromatography.

c) Recrystallized from the ethanol/benzene system. Purified by methanol-washing unless noted.
${ }^{1} \mathrm{H}$ NMR $\delta^{\mathrm{CDCl}_{3}} \mathrm{ppm}: 6.54(\mathrm{lH}, \mathrm{d}, J=2.4 \mathrm{~Hz})$, $6.75(1 \mathrm{H}, \mathrm{dd}, J=8.8,2.4 \mathrm{~Hz}), 7.04(1 \mathrm{H}, \mathrm{d}, J=$ $8.0 \mathrm{~Hz}), 7.22(1 \mathrm{H}, \mathrm{d}, J=8.0 \mathrm{~Hz}), 7.4-7.7(5 \mathrm{H}$, m), 7.7-7.8 $(2 \mathrm{H}, \mathrm{m}), 8.11(1 \mathrm{H}, \mathrm{d}, J=8.8 \mathrm{~Hz})$

\section{Synthesis of 2-Chloro-4-trifluoromethyl- phenyl 3,4-Dinitrophenyl Ether (3)}

According to the method described above (2j), $m$-nitrophenol and 3,4-dichlorobenzotrifluoride were reacted to yield 2-chloro-4trifluoromethylphenyl 3-nitrophenyl ether. The yield was $89 \%$ and the boiling point was 150 $155^{\circ} \mathrm{C} / 0.2 \mathrm{mmHg}$.

Sixty three point five grams $(0.2 \mathrm{~mol})$ of the above product was dissolved in $150 \mathrm{ml}$ of 1,2 dichloroethane under cooling at $0^{\circ} \mathrm{C}$. A mixture of acids (concentrated sulfuric acid $52 \mathrm{~g}+$ concentrated nitric acid $15 \mathrm{~g}$ ) was added dropwise to the solution and allowed to stand at room temperature for $2 \mathrm{hr}$. The resulting solution was discharged into ice-cold water, and the precipitating crude crystals were re- 


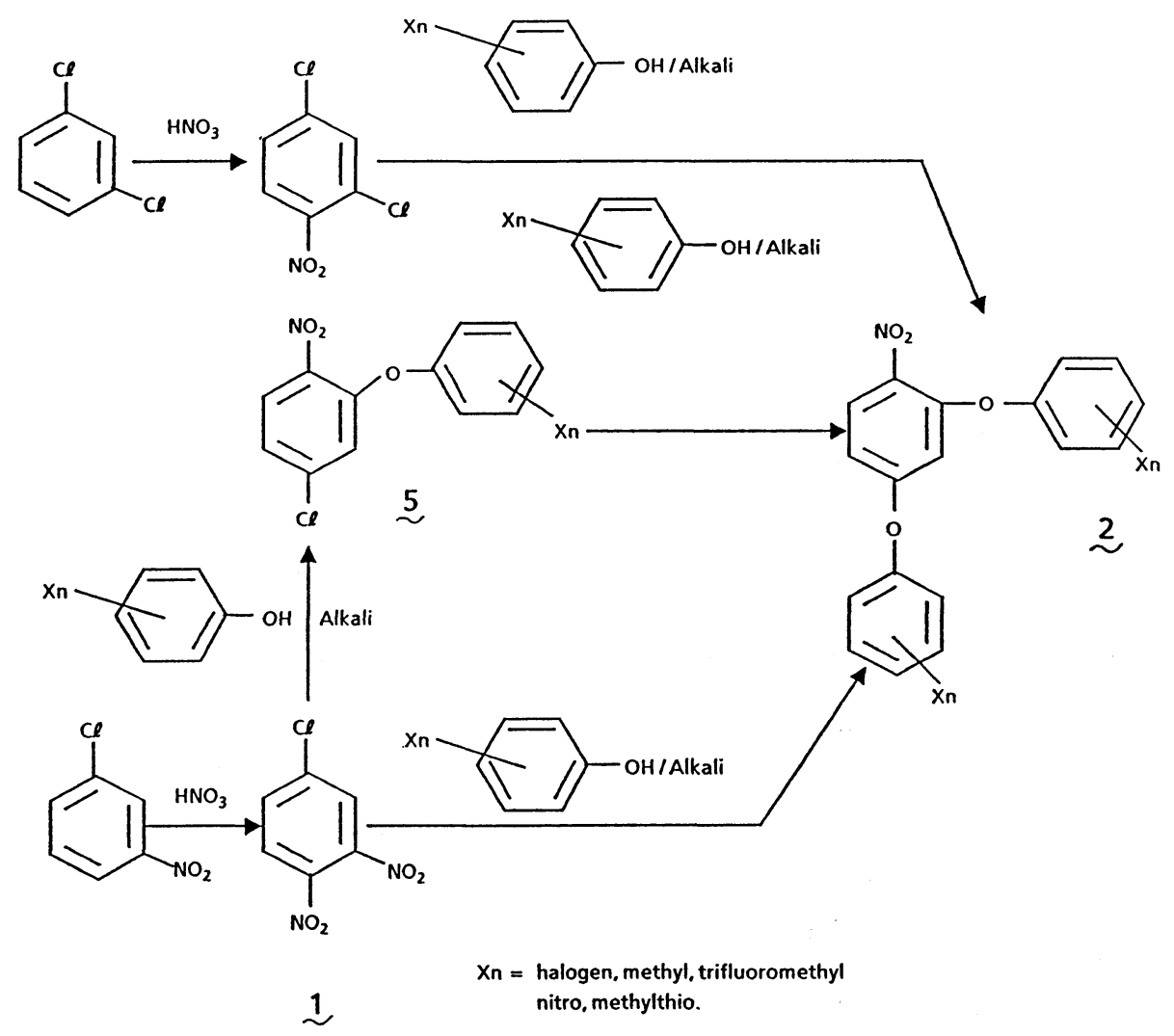

Fig. 4 Synthetic pathway of bis compounds (2).

crystallized from methanol. The yield was $91 \%(66 \mathrm{~g})$ and the melting point was $89-92^{\circ} \mathrm{C}$. $\mathrm{IR}^{\mathrm{KBr}} \mathrm{cm}^{-1}: 1520,1320$

${ }^{1} \mathrm{H}$ NMR $\delta^{\mathrm{CDCl}_{3}} \mathrm{ppm}: 7.16(1 \mathrm{H}, \mathrm{dd}, J=8.8$, $2.4 \mathrm{~Hz}), 7.28(1 \mathrm{H}, \mathrm{d}, J=2.4 \mathrm{~Hz}), 7.34(1 \mathrm{H}$, d, $J=8.8 \mathrm{~Hz}), 7.68(1 \mathrm{H}, \mathrm{dd}, J=8.8,2.4 \mathrm{~Hz})$, $7.83(1 \mathrm{H}, \mathrm{d}, J=2.4 \mathrm{~Hz}), 8.01(1 \mathrm{H}, J=8.8$ $\mathrm{Hz}$ )

5. Synthesis of 2,4-Dichlorophenyl 3-Hydroxy4-nitrophenyl Ether (4a) and Related Compounds $(\mathbf{4} \boldsymbol{b})-(\mathbf{4 l})$

In $200 \mathrm{ml}$ of tertiary butyl alcohol $(t-\mathrm{BuOH})$ were dissolved $44.5 \mathrm{~g}(0.1 \mathrm{~mol})$ of 2,4 -bis $(2,4-$ dichlorophenoxy)nitrobenzene and $8 \mathrm{~g}$ (0.13 mol) of thoroughly crushed $85 \% \mathrm{KOH}$, and the reaction mixture was heated at $70-75^{\circ} \mathrm{C}$ for $2 \mathrm{hr}$. The solution was cooled, and the resulting precipitate was collected by filtration and washed with water to obtain $29 \mathrm{~g}$ of orange-red material.
This product of very high purity was suspended in water and neutralized with hydrochloric acid. The yield was $85 \%$ and the melting point was $73.5-74.5^{\circ} \mathrm{C}$.

Eighteen grams $(0.05 \mathrm{~mol})$ of 2-chloro-4trifluoromethylphenyl 3,4-dinitrophenyl ether (3) and $3.4 \mathrm{~g}(0.05 \mathrm{~mol})$ of $85 \% \mathrm{KOH}$ were mixed and kept at $39^{\circ} \mathrm{C}$ for $3 \mathrm{hr}$. The similar procedure as above gave (4d) with a yield of $88 \%(14.6 \mathrm{~g})$ at a melting point of $71.1-72.6^{\circ} \mathrm{C}$. See also Fig. 6 and Fig. 7.

$\mathrm{IR}^{\mathrm{KBr}} \mathrm{cm}^{-1}: 1520,1345$

${ }^{1} \mathrm{H}$ NMR $\delta^{\mathrm{CDCl}_{3}} \mathrm{ppm}: 6.43(1 \mathrm{H}, \mathrm{d}, J=2.4$ $\mathrm{Hz}), 6.56(1 \mathrm{H}$; dd, $J=8.8,2.4 \mathrm{~Hz}), 7.10(1 \mathrm{H}$, d, $J=8.8 \mathrm{~Hz}), 7.34(1 \mathrm{H}, \mathrm{dd}, J=8.8,2.4 \mathrm{~Hz})$, $7.51(1 \mathrm{H}, \mathrm{d}, J=2.4 \mathrm{~Hz}), 8.08(1 \mathrm{H}, \mathrm{d}, J=$ $8.8 \mathrm{~Hz}), 10.76(1 \mathrm{H}, \mathrm{S})$

The above reaction took place without $t$ $\mathrm{BuOH}$ in the reaction system, but had to be aided by heating at a high temperature of $130^{\circ} \mathrm{C}$ or higher. Melting points of the prod- 
Table 3 Melting points of 2-nitro-5-(substituted phenoxy) phenols.

\begin{tabular}{|c|c|c|}
\hline $\begin{array}{c}\text { Compound } \\
\text { No. }\end{array}$ & Structure & $\begin{array}{c}\text { Melting } \\
\text { point }\left({ }^{\circ} \mathrm{C}\right)\end{array}$ \\
\hline
\end{tabular}

$4 a$<smiles>O=[N+]([O-])c1ccc(Oc2ccc(Cl)cc2Cl)cc1O</smiles>

$73.2-74.5$

$\mathbf{4 b}$<smiles>O=[N+]([O-])c1ccc(Oc2c(Cl)cc(Cl)cc2Cl)cc1O</smiles>

$121.8-123.0$

4c<smiles>O=[N+]([O-])c1ccc(Oc2c(F)cc(Cl)cc2Cl)cc1O</smiles>

88. 8-90.3

4d<smiles>O=[N+]([O-])c1ccc(Oc2ccc(C(F)(F)F)cc2Cl)cc1O</smiles>

$71.1-72.6$

$4 e$<smiles>O=[N+]([O-])c1ccc(Oc2ccccc2Cl)cc1O</smiles>

$80.0-81.2$

$4 f$<smiles>O=[N+]([O-])c1ccc(Oc2ccc([N+](=O)[O-])c(O)c2)c(Cl)c1</smiles>

139. 0-141.0

$4 g$<smiles>Cc1cc(Cl)ccc1Oc1ccc([N+](=O)[O-])c(O)c1</smiles>

67.3-68. 6

$4 h$<smiles>Cc1cc(Cl)cc(Cl)c1Oc1ccc([N+](=O)[O-])c(O)c1</smiles>

115. 1-116.2

$4 i$<smiles>O=[N+]([O-])c1ccc(Oc2cccc(C(F)(F)F)c2)cc1O</smiles>

$48.8-51.0$

4j<smiles>O=[N+]([O-])c1ccc(Oc2ccccc2)cc1O</smiles>

$116.0-117.0$

$4 k$<smiles>CSc1ccc(Oc2ccc([N+](=O)[O-])c(O)c2)cc1</smiles>

68. 0-70.0

\section{DISCUSSION}

1. Synthesis of 2,4-Bis(substituted phenoxy)nitrobenzene (2)

Conventional methods for synthesis of 2,4bis(substituted phenoxy)-nitrobenzene (2) involve condensation reaction of 2,4-dichloronitrobenzen with substituted phenols. ${ }^{2)}$ 2,4Dichlorophenol was used as a substituted phenol and reaction was done in DMF with potassium carbonate as a condensing agent. Thus, 2,4-bis(2,4-dichlorophenoxy)nitrobenzene was obtained with a high yield.

In the present study 3,4-dinitrochlorobenzene (1) was used instead of 2,4-dichloronitrobenzene. The nitro group at the 3 -position shows very high reactivity with nucleophilic reagents, but has not get been used for such synthetic purposes as stated above.

This method of synthesis using 3,4-dinitrochlorobenzene makes the procedure simpler and is likely to provide target compounds without any compromise in yield or purity. It has been confirmed that ( $\mathbf{1})$ can be prepared through nitration of $m$-chloronitrobenzene. ${ }^{3)}$ The compound (1) is condensed with a substituted phenol in the presence of alkali to give 2,4-bis(substituted phenoxy)nitrobenzene. In this system reaction proceed in two phases of conversion: from non (1) to mono substitution product (5) to bis substitution product (2) because of a considerable difference in reactivity between the nitro group at the 3-position and the chlorine atom at the 1-position of 3,4-dinitrochlorobenzene (Fig. 4).

In the conversion of $(\mathbf{1})$ to $(\mathbf{5})$ the nitro group at the 3-position easily reacts at temperatures near the boiling point of methanol, but no bis substitution product (2) is formed under these conditions. 2,4-Bis(2-chloro-4trifluoromethylphenoxy)nitrobenzene $(\mathbf{2} \mathbf{j})$ was prepared by a known method ${ }^{4)}$ as shown in Fig. 5. The point of this method is the first condensation reaction; it is difficult to control the reaction in such a way that an intermediate 3 - (2 - chloro - 4 - trifluoromethylphenoxy) phenol (7) is completely consumed to give product (6) with a high yield. If the reaction proceeds in excess, tar is formed as an undesired byproduct. ucts thus obtained are shown in Table 3 and the results by using tertiary alcohols or water are shown in Tables 4 and 5 . 
Table 4 Results of synthesis of 2-nitro-5-(substituted phenoxy)phenols (1)-tertiary alcohol method.

\begin{tabular}{|c|c|c|c|c|c|c|c|c|}
\hline \multirow{3}{*}{$\begin{array}{c}\text { Compound } \\
\text { No. }\end{array}$} & \multicolumn{3}{|c|}{ Conditions of reaction } & \multicolumn{5}{|c|}{ Yield of target compound $(\%)$} \\
\hline & \multicolumn{2}{|l|}{ Alkali } & \multirow{2}{*}{ Solvent } & \multicolumn{2}{|c|}{ Reaction } & \multirow{2}{*}{$\begin{array}{l}\text { Alkali } \\
\text { metal } \\
\text { salt }\end{array}$} & \multirow{2}{*}{$\begin{array}{l}\text { Crude } \\
\text { phenol }\end{array}$} & \multirow{2}{*}{$\begin{array}{l}\text { Purified } \\
\text { phenol }\end{array}$} \\
\hline & Form & $\begin{array}{l}\text { Molar } \\
\text { ratio }^{a} \text { ) }\end{array}$ & & $\begin{array}{l}\text { Temp. } \\
\left({ }^{\circ} \mathrm{C}\right)\end{array}$ & $\underset{(\mathrm{hr})}{\text { Time }}$ & & & \\
\hline $\mathbf{4 a}$ & $\mathrm{KOH}$ (solid) & 2.0 & 1,1-Dimethylpropanol & 70 & 4 & 98.5 & 96.8 & 93.3 \\
\hline $4 a$ & $\mathrm{NaOH}$ (solid) & 2.1 & $t$-Butanol & 80 & 3 & 99.0 & 97.5 & 94.5 \\
\hline $4 b$ & $\mathrm{KOH}(50 \%$ aq) & 2.2 & $\alpha, \alpha$-Dimethylbenzyl alcohol & 80 & 3 & 99.4 & 97.2 & 95.0 \\
\hline $\mathbf{4 h}$ & $\mathrm{KOH}$ (solid) & 2.3 & $t$-Butanol & 80 & 4 & 96.2 & 94.7 & 92.8 \\
\hline 4d & $\mathrm{KOH}(50 \% \mathrm{aq})$ & 2.2 & 1,1-Dimethylpropanol & 70 & 5 & 92.0 & 88.6 & 85.3 \\
\hline $4 d$ & $\mathrm{NaOH}$ (solid) & 2.3 & $t$-Butanol & 80 & 4 & 93.2 & 90.9 & 88.5 \\
\hline $4 \mathrm{~g}$ & $\mathrm{KOH}$ (solid) & 2.0 & $t$-Butanol & 90 & 3 & 97.8 & 94.2 & 90.0 \\
\hline $4 e$ & $\mathrm{NaOH}$ (solid) & 2.0 & 1,1-Dimethylpropanol & 60 & 6 & 98.2 & 97.0 & 94.8 \\
\hline $4 g$ & $\mathrm{KOH}(50 \%$ aq) & 2.0 & $t$-Butanol & 80 & 4 & 92.2 & 89.8 & 86.7 \\
\hline $4 e$ & $\mathrm{KOH}$ (solid) & 2.2 & $t$-Butanol & 60 & 4 & 98.3 & 96.6 & 93.8 \\
\hline
\end{tabular}

a) Molar ratio based on the corresponding bis-compounds (2).

Table 5 Results of synthesis of 2-nitro-5-(substituted phenoxy)phenols (2)-aqueous solution method.

\begin{tabular}{|c|c|c|c|c|c|c|c|c|c|}
\hline \multirow{3}{*}{$\begin{array}{l}\text { Com- } \\
\text { pound } \\
\text { No. }\end{array}$} & \multicolumn{4}{|c|}{ Conditions of reaction } & \multicolumn{5}{|c|}{ Yield of target compound (\%) } \\
\hline & \multicolumn{3}{|c|}{ Alkali } & \multirow{2}{*}{ Additive } & \multicolumn{2}{|c|}{ Reaction } & \multirow{2}{*}{$\begin{array}{c}\text { Alkali } \\
\text { metal } \\
\text { salt }\end{array}$} & \multirow{2}{*}{$\begin{array}{l}\text { Crude } \\
\text { phenol }\end{array}$} & \multirow{2}{*}{$\begin{array}{c}\text { Purified } \\
\text { phenol }\end{array}$} \\
\hline & Form & $\begin{array}{l}\text { Molar } \\
\text { ratio }^{\text {a) }}\end{array}$ & $\begin{array}{c}\text { Conc. } \\
(\%)\end{array}$ & & $\underset{\left({ }^{\circ} \mathrm{C}\right)}{\text { Temp. }}$ & $\underset{(\mathrm{hr})}{\text { Time }}$ & & & \\
\hline $\mathbf{4 a}$ & $\mathrm{NaOH}$ & 5 & 50 & $O$-Dichlorobenzene & 130 & 4 & 93.6 & 90.9 & 79.2 \\
\hline $\mathbf{4 b}$ & $\mathrm{KOH}$ & 5 & 50 & - & 130 & 1.5 & 93.0 & 91.1 & 84.4 \\
\hline 4c & $\mathrm{KOH}$ & 5 & 50 & - & 130 & 1 & 97.6 & 95.1 & 81.1 \\
\hline $4 d$ & $\mathrm{KOH}$ & 10 & 67 & 1,2,4-Trimethylbenzene & 150 & 5 & 72.5 & 70.2 & 59.3 \\
\hline $\mathbf{4 e}$ & $\mathrm{NaOH}$ & 5 & 50 & - & 140 & 2.5 & 84.0 & 82.1 & 70.5 \\
\hline $4 e$ & $\mathrm{KOH}$ & 5 & 50 & $\begin{array}{l}\text { Ethylene glycol dimethyl } \\
\text { ether }\end{array}$ & 130 & 5 & 74.8 & 70.7 & 57.5 \\
\hline $4 f$ & $\mathrm{KOH}$ & 4 & 40 & - & 120 & 0.5 & 42.3 & 40.5 & 22.5 \\
\hline $4 \mathrm{~g}$ & $\mathrm{KOH}$ & 5 & 50 & - & 130 & 3 & 82.6 & 79.3 & 60.4 \\
\hline $4 h$ & $\mathrm{KOH}$ & 10 & 67 & 1,2,4-Trimethylbenzene & 150 & 3 & 64.4 & 62.5 & 51.3 \\
\hline $\mathbf{4 i}$ & $\mathrm{KOH}$ & 10 & 67 & - & 140 & 2 & 95.6 & 93.1 & 82.5 \\
\hline $4 j$ & $\mathrm{KOH}$ & 10 & 67 & 1,2,4-Trimethylbenzene & 140 & 4 & 88.5 & 85.7 & 71.1 \\
\hline $4 k$ & $\mathrm{KOH}$ & 5 & 50 & $O$-Dichlorobenzene & 130 & 3 & 90.6 & 87.1 & 76.2 \\
\hline
\end{tabular}

a) Molar ratio based on the corresponding bis-compounds (2).

2. Synthesis of 2-Chloro-4-trifluoromethylphenyl 3,4-Dinitrophenyl Ether (3)

Diphenyl ether compounds $(\mathbf{8})$ with a strong herbicidal action are generally prepared by using compound $(\mathbf{2} \mathbf{j})^{4)}$ or $(\mathbf{1 1})^{5)}$ as an intermediate material, as shown in Fig. 6.

In these methods problems are the selectivity of reaction and the recycle of leaving components. Aimed to eliminate these prob- lems, studies were conducted to find a new route that would allow to utilize 2-chloro-4trifluoromethylphenyl 3,4-dinitrophenyl ether (3) as an intermediate material. This method was satisfactory with to both selectivity of reaction and procedure.

Methods for synthesizing compound (8) from compounds $(\mathbf{2} \mathbf{j}),(\mathbf{3})$ and $(\mathbf{1 1})$ will be discussed in detail elsewhere. ${ }^{6}$ 


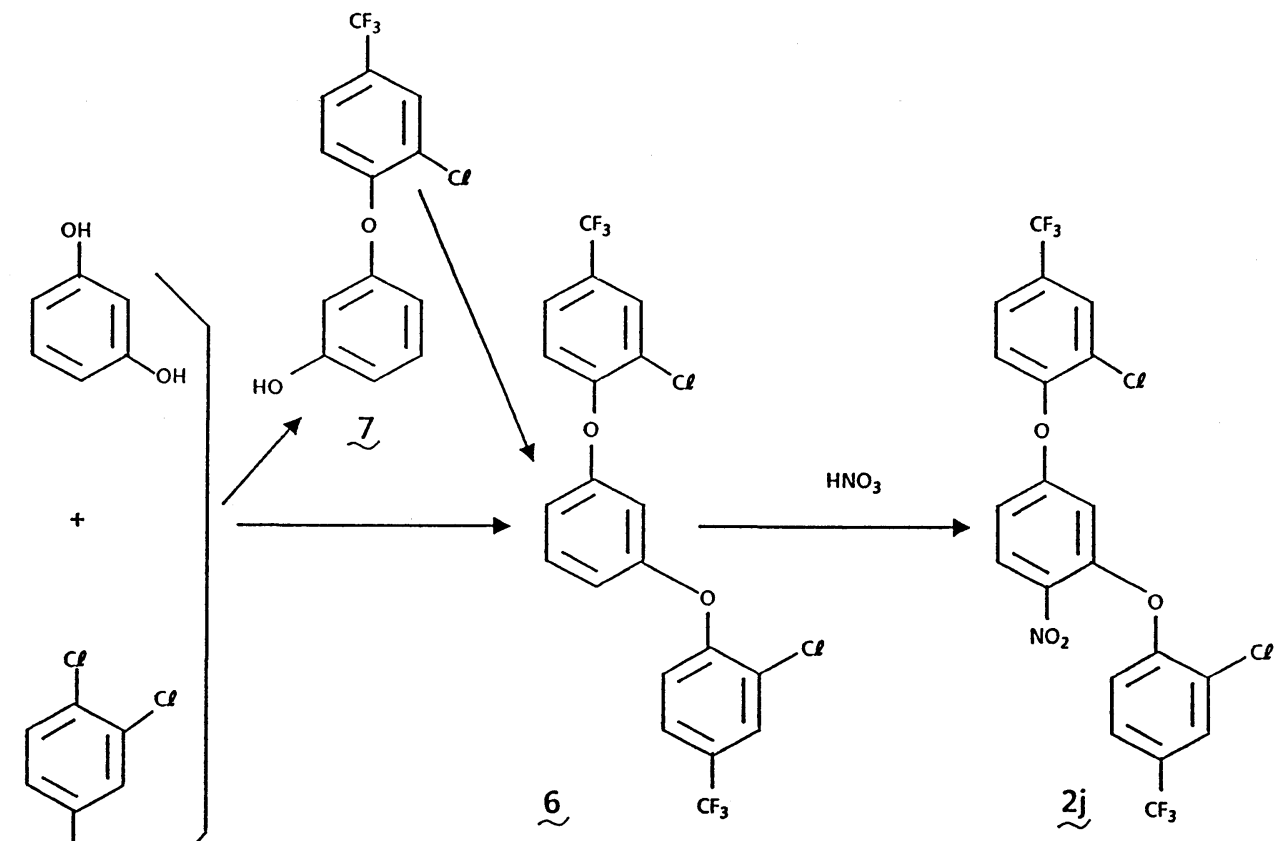

Fig. 5 Synthetic pathways of 2,4-bis(2-chloro-4trifluoromethyl phenoxy) nitrobenzene $(\mathbf{2} \mathbf{j})$.
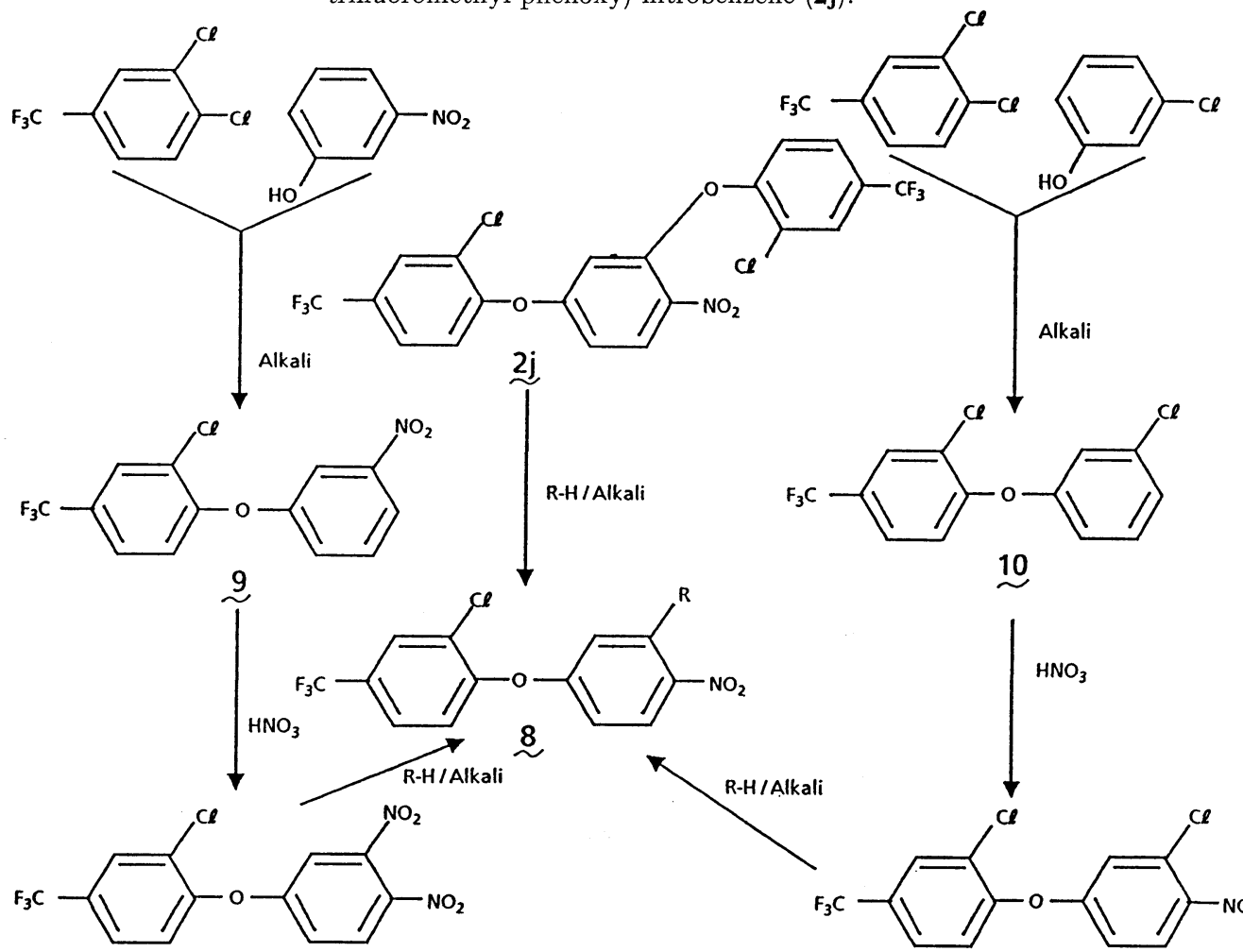

$\stackrel{3}{\sim}$

$R=$ alkoxy, alkylthio, alkylamino alkoxycarbonyl methylthio.

Fig. 6 Synthetic pathways of herbicidal compounds (8). 
If compound $(\mathbf{2} \mathbf{j})$ is used, 2-chloro-4-trifluoromethylphenol is released as a leaving component. Problem with $(\mathbf{2} \mathbf{j})$ is that the $\mathrm{CF}_{3}$ group of 2-chloro-4-trifluoromethylphenol is so unstable in the presence of alkali as to liberate a carboxylic acid derivative.

Use of compound (11) also presents two problems. First, when compound $(\mathbf{1 0})$ is nitrated, the positional isomer 2-chloro-4trifluoromethylphenyl 2-nitro-5-chlorophenyl ether is formed as a by-product at a ratio of $25-30 \%$. Second, the separation of each isomer is fraught with difficulty.

On the other hand, production of an isomer as a by-product was extremely limited in nitration of (9). Since the nitration was a very selective reaction, the content of $(\mathbf{3})$ in the crude product was so high along with its crystallinity that it could be easily purified. The nitro group at the 3 -position of $(\mathbf{3})$ is more reactive than both phenoxy group of $(\mathbf{2} \mathbf{j})$ and chlorine atom of $(\mathbf{1 1})$. In the case of the nucleophilic reactions shown in Fig. 6, (3) has the advantage of being amenable to prepare (8) under mild condition.

\section{Synthesis of 2-Nitro-5-(substituted phenoxy)- phenol (4)}

A few synthesis methods of phenoxyphenols (4) have so far been reported. Of these methods, $\mathrm{O}-\mathrm{CH}_{3}$ bond cleavage of (12) by hydrobromic acid $^{7)}$ shows a tolerable yield; (4) can also be obtained by decomposing (13) via diazotization, but the procedures are complicated and also the yield is not satisfactory.

Diphenyl ether compounds having a nitro group at the positions ortho and/or para to ether oxygen have a weak ether bond so that it breaks on reacting with alkali hydroxide ${ }^{8,9)}$ or amines. ${ }^{10,11)}$ In this study, however, 2,4bis(phenoxy)nitrobenzenes (2) were reacted with alkali to yield (4) with high selectivity.

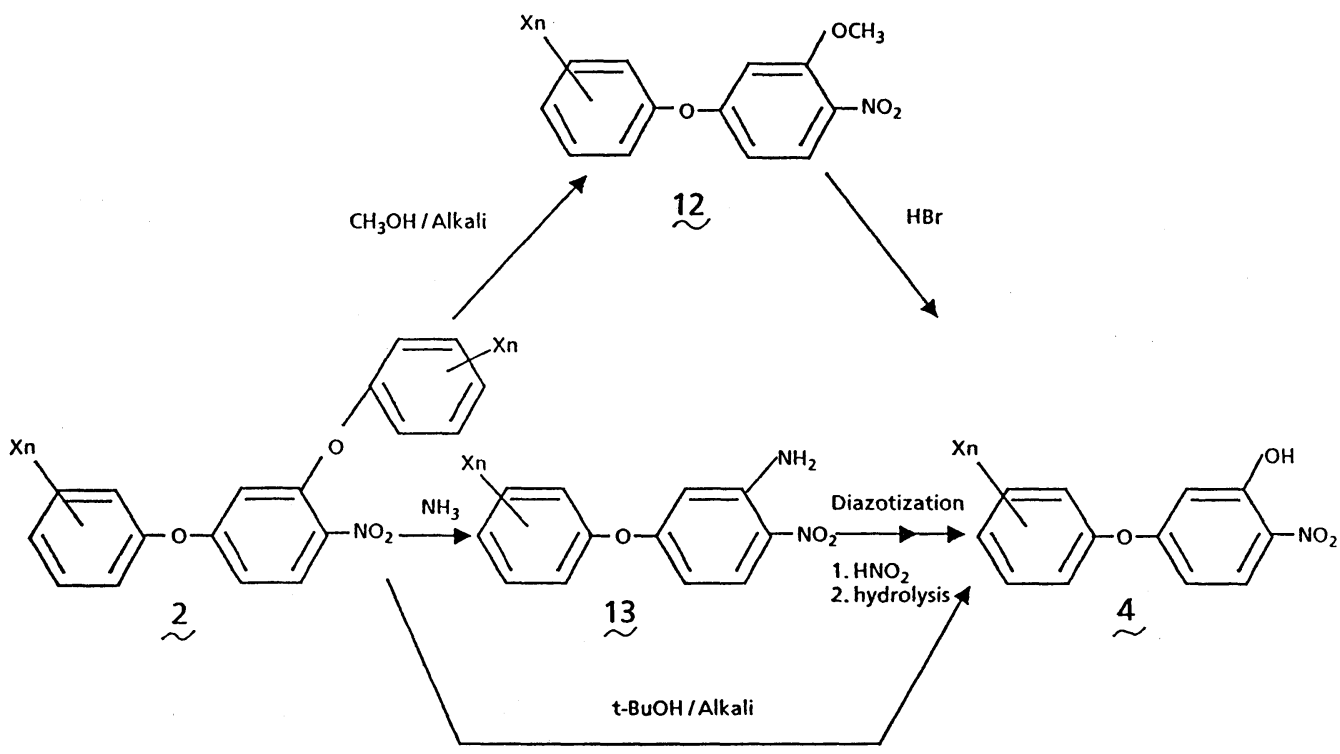

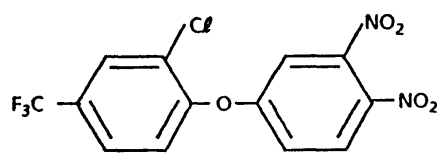

3

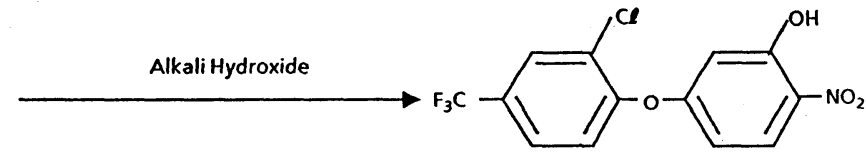

$\stackrel{4 d}{\sim}$

Fig. 7 Synthetic pathways of 2-nitro-5-(substituted phenoxy) phenols $(\mathbf{4}, \mathbf{4 d})$. 
In the same manner, 2-chloro-4-trifluoromethylphenyl 3,4-dinitrophenyl ether (3) were reacted with alkali to yield (4d) with high selectivity. The reactivity of the nitro group at the 3-position was suggested more selective than the substituted phenoxy group at the 3position.

These alkali catalyzed hydrolysis of (2) or (3) for synthesis of 2-nitro-5-(substituted phenoxy)phenol is by far superior to reactions via compound (12) or (13). See Fig. 7.

The reaction of (2) with alkali metal and primary alcohol to diphenyl ether was already reported. ${ }^{12)}$ For instance, when an ethanolic solution of (2a) was added dropwise to ethanolic potassium hydroxide red color appeared momentarily. When the solution is stirred at $30-50^{\circ} \mathrm{C},(\mathbf{1 4})$ was obtained in large quantities. Ether exchange reaction was assumed to proceed through a Meisenheimer-type intermediate (15). The reaction is schematically represented in Fig. 8.

An attempt was made to prepare (4a) by reacting ethanolic potassium hydroxide with isolated (14) under severe conditions, but in vain, (16) was obtained with a high yield instead of $(\mathbf{4 a})$, as shown in Fig. 8.

Compound (4) could not be obtained by this method, since the reaction of 2,4-bis(substituted phenoxy)nitrobenzene with alcoholic potassium hydroxide proceeded in the manner shown in Fig. 9.

Reaction was repeated with secondary or tertiary alcohols instead of ethanol to yield hydroxy compound (4a) as desired. With secondary alcohol, hydroxy and ether type compounds were formed at the same time, and the ratio of these products differed from one kind of alcohol to another. See Table 6. With of tertiary alcohol, no ether type compound was formed, but a hydroxy type compound was formed in large quantities. The results

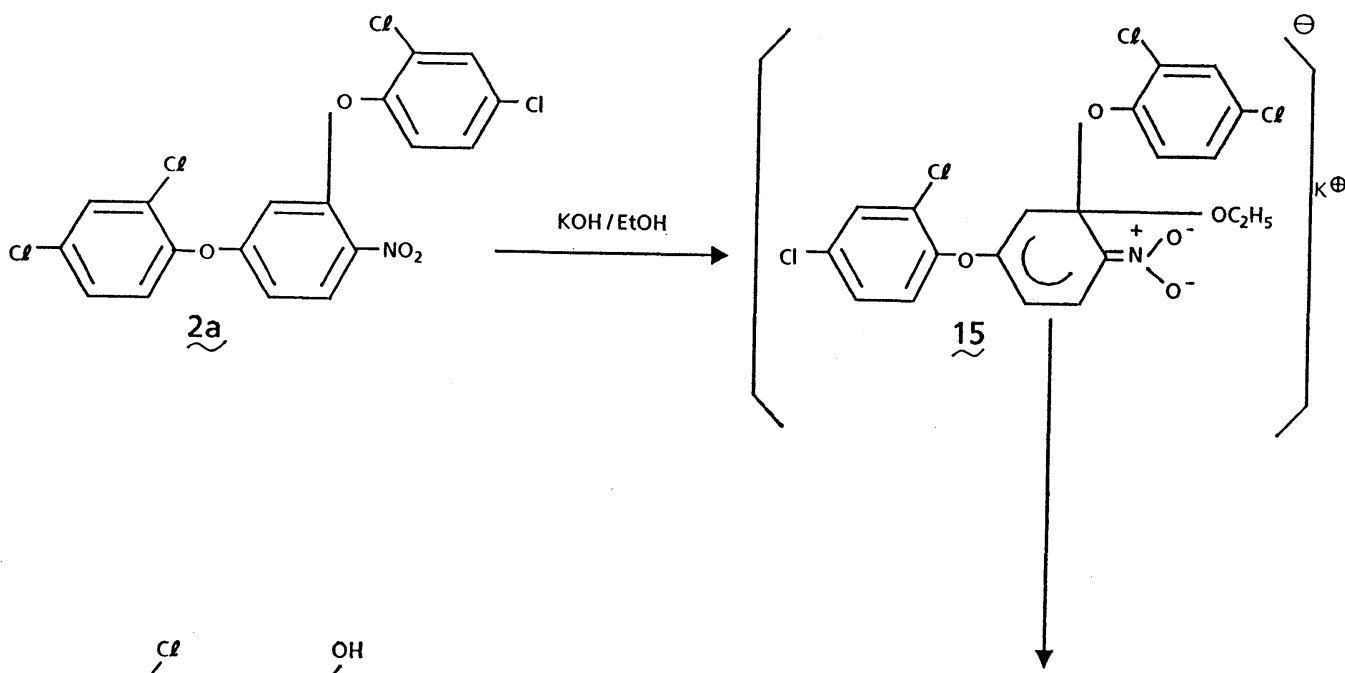

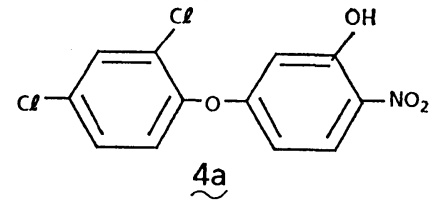

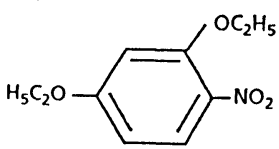

16
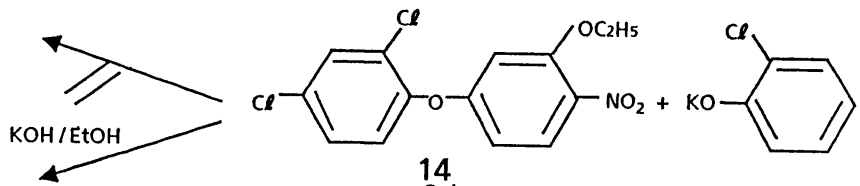

14

Fig. 8 Reaction of 2,4-bis(2,4-dichlorophenoxy) nitrobenzene with ethanolic potassium hydroxide. 


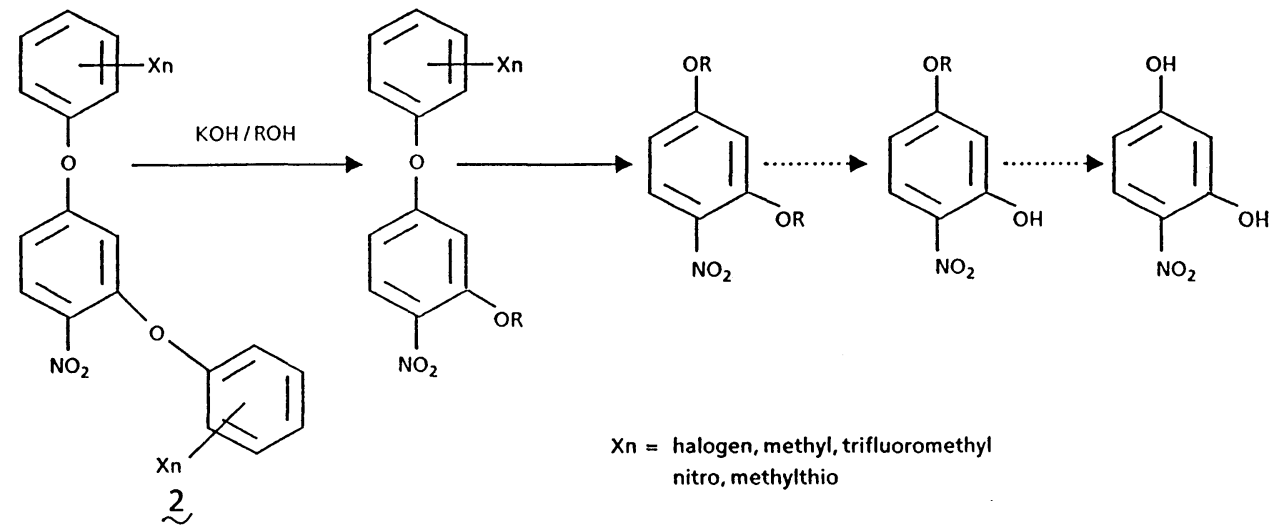

Fig. 9 Reaction sequence of bis compounds with primary alcoholic $\mathrm{KOH}$.

Table 6 Reaction products of 2,4-bis(2,4-dichlorophenoxy)nitrobenzene with potassium hydroxide in alcohols.

\begin{tabular}{|c|c|c|}
\hline Solvent & \multicolumn{2}{|c|}{$\begin{array}{l}\text { Reaction product } \\
\text { (in molar ratio) }\end{array}$} \\
\hline Alcohol & $\begin{array}{l}\text { Hydroxy } \\
\left.\text { compound }^{a}\right)\end{array}$ & $\begin{array}{l}\text { Ether } \\
\text { compound }\end{array}$ \\
\hline 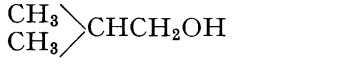 & 0 & $100^{\mathrm{b})}$ \\
\hline $\begin{array}{l}\mathrm{CH}_{3} \mathrm{CH}_{2} \\
\mathrm{CH}_{3}\end{array}>\mathrm{CHOH}$ & 15.5 & $84.5^{c, e)}$ \\
\hline $\begin{array}{l}\left(\mathrm{CH}_{3}\right)_{2} \mathrm{CHCH}_{2} \mathrm{CH}_{2} \\
\left(\mathrm{CH}_{3}\right)_{2} \mathrm{CHCH}_{2} \mathrm{CH}_{2}\end{array}>\mathrm{CHOH}$ & 43 & $57^{\mathrm{d}, \mathrm{e})}$ \\
\hline$\left(\mathrm{CH}_{3}\right)_{3} \mathrm{COH}$ & 100 & 0 \\
\hline $\mathrm{CH}_{3} \mathrm{CH}_{2} \cdot \mathrm{C} \cdot\left(\mathrm{CH}_{3}\right)_{2} \mathrm{OH}$ & 100 & 0 \\
\hline $1 /-\mathrm{C}\left(\mathrm{CH}_{3}\right)_{2} \mathrm{OH}$ & 100 & 0 \\
\hline
\end{tabular}

a) Hydroxy compound.

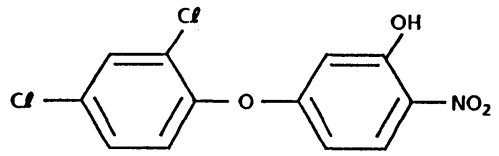

b, c, d) Ether compound.

e) Separated by column chromatography.

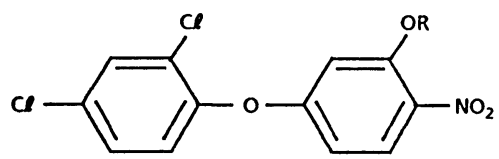

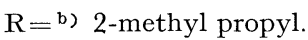

c) 1-methyl propyl.

d) 1-(4-methyl butyl) 5-methyl pentyl.

Molar ratio of materials: 2,4-Bis(2,4-dichlorophenoxy)nitrobenzene (2a): Potassium hydroxide $=1: 2$

Solvent: 4 times (2a) by weight.

Conditions of reaction: $70^{\circ} \mathrm{C}$ for $3 \mathrm{hr}$. of experiments are represented in Table 6 . With tertiary alcohol, the influence of substituent groups of (2) was so negligible that all the compounds reacted smoothly. As a result, target compounds (4) were obtained as desired. See Table 4.

Target compounds (4) were also obtained through hydrolysis in alkaline solution without the aid of alcohol. It was found that the phenoxy group on the ortho position reacted more selectively than the nitro group in spite of high-temperature conditions in the presence of excess alkali. With a two-phase system using inert solvents such as $o$-dichlorobenzene, violent reaction was depressed and reaction proceeded smoothly.

The alkali metal salt of (4) was easily obtained by filtration with cooling since it was sparingly soluble in cold water. The alkalimetal salt was suspended in water and neutralized with a suitable acid to obtain 2-nitro5-(substituted phenoxy)phenol. When water was a solvent, the yield and ratio of formation of (4) differed with substituent groups of bis compound (2).

Compounds with a methyl group, $(\mathbf{2 g})$ and (2h), hardly decomposed.

The yield of (4f) with a compound having a highly electronegative nitro group (2f) was the lowest, and the reaction product contained several constituents. It is assumed that the two ether bonds at the ortho and para positions were cleft unselectively.

The yield of (4) was high with compounds having halogens at the 2-,4- and 6-positions 
$[(\mathbf{2 b})$ and $(\mathbf{2 i})]$ and the compound with chlorine at the meta position.

Unlike a compound with a nitro group at the para position (4f), the ether bond was not creft with a compound having a trifluoromethyl group at the para position (4d). Actually the reaction rate was the slowest of all.

The reason for this is presumed that alkali was consumed by side reaction of by-products to a large extent, and insufficient alkali was left for main reaction at $120-140^{\circ} \mathrm{C}$ in an aqueous solution.

The trifluoromethyl group of 2-chloro-4trifluoromethylphenol was further reacted with alkali and 3-chloro-4-hydroxybenzoic acid was formed.

Thus, potassium hydroxide was consumed in large quantities and the main reaction was inhibited to reduce the apparent speed of the reaction.

When the same reaction was done in tertiary alcohol at a lower temperature of about $80^{\circ} \mathrm{C}$, secondary decomposition of 2-chloro-4trifluoromethyl phenol was depressed so that the greater part of it was recovered.

\section{A comparison of Processes for $(\mathbf{4 d})$}

With respect to the preparation of 2-nitro5-(2-chlorotrifluoromethylphenoxy)phenol (4d) an important intermediate of diphenyl ether herbicides. We tried two processes starting from (2f) and (3).

By using (3), though a leaving group is nitro, alkali requirement was consumed in an equimolecular amount of $(\mathbf{3})$. And also the removal by-product 2-chloro-4-trifluoromethyl phenol was unnecessary, different from the case of (2f).

As the comparison of the two processes suggests, (3) is obviously a versatile intermediate that increases the efficiency in synthesis of useful diphenyl ether herbicides.

\section{ACKNOWLEDGMENTS}

We wish to express our thanks to Mr. Masaaki Ura and Mr. Naoki Satoh for their skilled technical assistance.

\section{REFERENCES}

1) S. Matsunaka: "Shokubutsu dokurigaku niumon," Tokyo Univ. Shuppankai, p. 30, 1976

2) P. Petitcolas (Compagnie Nationale de Matieres Colorants): USP-2,141,667 (1937)

3) A. Laubenheimer: Chem. Ber. 9, 760 (1876)

4) C. Swithenbank \& R. Y. Yih (Rohm \& Haas Co.): USP-3,798,276 (1974)

5) R. Lothar \& S. Juergen (Bayer AG): BE817,029 (1973)

6) T. Yoshimoto, K. Igarashi, K. Oda \& Y. Funakoshi: unpublish data

7) W. Harold \& F. Marvin (Rohm \& Haas Co.): Jpn. Tokkyo Koho JP47-40,365 (1972)

8) J. Reilly: J. Chem. Soc. 67 (1927)

9) K. Matsumura: J. Am. Chem. Soc. 52, 3199 (1930)

10) D. Lilianfax: J. Chem. Soc. 1853 (1930)

11) D. James Wood: J. Chem Soc. 1168 (1927)

12) R. Nishiyama, R. Takahashi, K. Fujikawa \& I. Yokomichi (Ishihara Mining \& Chem. Co.) : Jpn. Tokkyo Koho JP49-826 (1974)

\section{要約}

\section{ジフェニルエーテル系除草剤に関する中間体の 合成}

吉本武雄, 五十嵐桂一, 藤田 高, 原山威甫

Diphenyl ether 系除草率を効率よく製造するために基 本となる物質を追求した．従来，2-substituted-4-phenoxynitrobenzene 系の除草荗を製造する際，2,4-bis(substitutedphenoxy) nitrobenzene 2 を経由する方法が一般的 であり，その出発原料として 2,4-dichloronitrobenzene が 用いられている。これに代わる物質として 3,4-dinitrochlorobenzene 1 をとりあげ，その反応性と選択性の差 異を明らかにした。まず，phenol 類と 1 を反応させ 2 を効率よく合成した．さらに 1 の塩素元子の置換体とし $\tau 2$-chloro-4-trifluoromethylphenyl 3,4-dinitrophenyl ether $\mathbf{3}$ を合成した． 3 の nitro 基も 1 の場合と同様に強 い反応性を保持し種種の求核試薬との反応性に富む. 次 に 2,3 を用い $\mathrm{NaOH}$ または $\mathrm{KOH}$ による開裂反応を試 み Substituted phenyl 3-hydroxy-4-nitrophenyl ether 4 へ誘導した．以上で得た $2,3,4$ は 4-位に nitro 基をも $つ$ diphenyl ether 系除草剤の主要な中間体としての活用 が期待できる. 